\title{
RESPON MAHASISWA TERHADAP PEMBELAJARAN MENGGUNAKAN MODEL SIKLUS BELAJAR 5E PADA MATERI HUKUM DASAR KIMIA
}

\author{
Lukman Hadi, M.Pd ${ }^{1}$ \\ Prodi Pendidikan Kimia FKIP UNTAN \\ Email: allongsambas@yahoo.com
}

\begin{abstract}
Abstrak
Penelitian ini bertujuan mengetahui respon mahasiswa terhadap pembelajaran menggunakan model siklus belajar 5E pada hukum dasar kimia. Untuk menjawab permasalahan digunakan metode pra-eksperimen dengan desain one-shot case study. Subjek penelitian adalah 25 mahasiswa PGMIPAU Tahun 2014. Teknik pengumpulan data menggunakan komunikasi tak langsung. Berdasarkan hasil penelitian diperoleh informasi bahwa mahasiswamemberikan respon yang baik terhadap pembelajaran menggunakan model siklus belajar 5E pada materi hukum dasar kimia.
\end{abstract}

This study was aimed to know students' responses towards 5e learning cycle model on law of fundamental chemistry course. One-shot case study design was used to answer the research problem. Research subject are 25 students of PGMIPAU class. Indirect communication technique was usedto collect data. Result of this research informed that students had given good responses towards 5e learning cycle model on law of fundamental chemistry course.

Kata-kata kunci:Model siklus belajar 5E, respon, hukum dasar kimia.

Mata pelajaran kimia merupakan salah satu mata pelajaran yang sulit bagi peserta didik. Menurut Sirhan (2007) karena topik kimia umumnya terkait dengan struktur dari suatu materi, hal ini membuat kimia menjadi pelajaran yang sulit bagi banyak peserta didik. Disamping itu, kimia merupakan mata pelajaran yang banyak mempelajari konsep abstrak (Adaminata \& Marsih, 2011), yang memerlukan komitmen waktu dan usaha dari peserta didik (Wu \&

${ }^{I}$ Lukman Hadi adalah dosen Prodi Kimia FKIP Untan 
Foos, 2010). Keabstrakan ini ditambah dengan adanya konsep yang berlawanan dengan intuisi menjadikan kimia sebagai pelajaran yang kompleks, sehingga menyebabkan banyak kesulitan bahkan miskonsepsi pada mahasiswa.

Kesulitan ini salah satunya dapat ditemukan pada materi hukum dasar kimia, dimana selama ini mahasiswa hanya memahami materi ini berdasarkan fenomena yang tampak saja. Sebagai contoh, pada pembuktian hukum kekekalan massa, mahasiswa dapat mengamati massa zat sebelum dan setelah bereaksi adalah sama untuk reaksi yang tidak menghasilkan gas atau dilakukan pada wadah tertutup. Pada reaksi yang menghasilkan gas dan dilakukan pada wadah terbuka akan diperoleh massa zat sebelum dan setelah reaksi yang berbeda. Perbedaan massa zat sebelum dan setelah reaksi tersebut membuat mahasiswa berasumsi bahwa hukum kekekalan massa tidak terjadi pada reaksi tersebut, padahal apabila gas yang dihasilkan ditampung di dalam wadah dan di timbang massanya, maka akan memperoleh massa zat sebelum dan setelah reaksi yang sama. Berdasarkan penjelasan di atas diperlukan suatu pendekatan pembelajaran yang dapat membantu mahasiswa dalam membangun pemahaman dan pola pikirnya terhadap konsep yang dipelajari secara mandiri.

Menurut Prawiradilaga (2009)konstruktivisme menyiapkan peserta didik untuk membentuk pemahaman dan pola pikir tersendiri. Pendekatan konstruktivis berpijak pada prinsip fundamental yang menganggap apa yang sudah diketahui peserta didik menjadi faktor utama dalam menentukan hasil dari pembelajaran dan menyediakan kesempatan kepada peserta didik untuk mengembangkan pemahaman baru dengan pendidik bertindak sebagai fasilitator pembelajaran daripada sebagai penyampai pengetahuan (Ausubel, 1968 dalam Gilbert \& Treagust, 2009). Pada pertemuan konstruktivis yang khas, peserta didik bekerja pada masalah dan campur tangan guru hanya diperlukan untuk membimbing peserta didik ke arah yang sesuai (Cooperstein \& Kocevar Weidinger, 2004).Beberapa strategi pembelajaran dengan pendekatan konstruktivis yang dapat digunakan di dalam pembelajaran kimia salah satunya adalah model siklus belajar (learning cycle/LC).

Model siklus belajar terdiri atas lima fase pembelajaran yang meliputi: Engagement, Exploration, Explanation, Elaboration, dan Evaluation(Lorsbach, 2002). Pada siklus belajar mahasiswa dapat mengidentifikasi suatu pola keteraturan dalam fenomena yang diselidiki, kemudian memperkenalkan konsep-konsep yang ada hubungannya dengan fenomena yang diselidiki dan mendiskusikannya dalam konteks apa yang telah diamati, selanjutnya menggunakan konsep-konsep yang telah diperkenalkan 
pada situasi baru. Pada penerapan di kelas, model ini dirangkai dalam lima fase kegiatan. Fase engagement dilakukan dengan membuat koneksi ke pengalaman masa lalu dan mengekspos miskonsepsi siswa dan mereka harus mengurangi ketidakseimbangan kognitif yang terjadi. Pada kegiatan ini dosen mengakses pengetahuan mahasiswa dan membantu mereka menjadi terlibat dalam sebuah konsep baru melalui penggunaan aktivitas singkat yang mendorong rasa ingin tahu dan menimbulkan pengetahuan sebelumnya. Kegiatan ini membuat hubungan antara pengalaman belajar masa lalu dan sekarang, terlebih dahulu mengungkapkan konsepsi, dan mengatur pemikiran mahasiswa terhadap aktivitas hasil belajar saat ini.

Fase exploration dilakukan dengan membangun pengalaman dosen dan mahasiswa yang dapat digunakan kemudian untuk memperkenalkan dan mendiskusikan konsep, proses, atau keterampilan. Pengalaman eksplorasi memberikan mahasiswa sebuah dasar aktivitas umum dimana konsep saat ini (yaitu, miskonsepsi), proses, dan keterampilan yang diidentifikasi dan perubahan konseptual yang difasilitasi. Mahasiswa dapat menyelesaikan kegiatan laboratoriumyang membantu mereka menggunakan pengetahuan sebelumnya untuk menghasilkan ide-ide baru, mengeksplorasi pertanyaan dan kemungkinan, serta desain dan melakukan penyelidikan awal.Lembar Kerja Mahasiswa (LKM) dapat digunakan pada fase ini untuk membantu proses awal merumuskan konsep yang memadai dan akurat. Menurut Cooperstein \& Kocevar Weidinger (2004) konsep-konsep abstrak menjadi berarti, ditransfer, dan disimpan karena mereka terikat dengan kinerja dari suatu kegiatan. Kegiatan pada fase exploration dapat mengarahkan pada penemuan konsep yang diajarkan dan dapat membangun makna dari konsep tersebut.

Fase explanation dilakukan dengan meminta mahasiswa menjelaskan pengalaman eksplorasi dan pengalaman engagement mereka dengan menggunakan istilah umum. Tahap Penjelasan memfokuskan perhatian mahasiswa pada aspek tertentu dari engagement dan pengalaman eksplorasi serta memberikan kesempatan untuk menunjukkan pemahaman konseptual mereka, keterampilan proses, atau perilaku. Fase ini juga memberikan kesempatan bagi dosen untuk langsung memperkenalkan konsep, proses, atau keterampilan. Mahasiswa menjelaskan pemahaman mereka tentang konsep. Penjelasan dari dosen dapat membimbing mereka ke arah pemahaman yang lebih dalam, yang merupakan bagian penting dari fase ini.

Fase elaboration dilakukan dengan melibatkan mahasiswa dalam situasi baru dan masalah yang memerlukan transfer penjelasan yang indentik 
atau mirip. Dosen memberikan tantangan dan memperluas pemahaman konseptual dan keterampilan mahasiswa. Melalui pengalaman baru, mahasiswa mengembangkan pemahaman yang lebih mendalam dan lebih luas serta informasi dan keterampilan yang memadai. Mahasiswa menerapkan pemahaman mereka tentang konsep dengan melakukan kegiatan tambahan.Fase evaluation dilakukan dengan memberikan penilaian terhadap pengetahuan, pemahaman konsep, atau kompetensi mahasiswa dalam konteks baru yang kadang-kadang mendorong mahasiswa belajar melakukan investigasi lebih lanjut, dengan cara refleksi pelaksanaan pembelajaran.Tahap evaluasi mendorong mahasiswa untuk menilai pemahaman dan kemampuan mereka dan memberikan kesempatan bagi dosen untuk mengevaluasi kemajuan mahasiswa untuk mencapai tujuan pendidikan.Menurut (Fajaroh \& Dasna, 2007) penerapan strategi ini memberi keuntungan meningkatkan motivasi belajar karena peserta didik dilibatkan secara aktif dalam proses pembelajaran. Berdasarkan penjelasan di atas, peneliti melakukan penelitian tentang implementasi model siklus belajar 5E pada materi hukum dasar kimiaterhadap responmahasiswa.

\section{Metode}

Penelitian ini termasuk penelitian pra-eksperimen, karena memberikan perlakuan model siklus belajar 5Epada materi hukum dasar kimia untuk mengetahui respon mahasiswa terhadap pembelajaran.Penelitian ini melibatkan25mahasiswa PGMIPAU Tahun 2014. Desain penelitian menggunakan one-shotcase study design.Teknik pengumpulan data yang digunakan di dalam penelitian ini adalah komunikasi tak langsung dengan instrumen yang digunakan berupa angket, di mana pengolahan data hasil penelitian menggunakan skala Likert.

\section{Hasil}

Respon mahasiswa diukur menggunakan angket respon mahasiswa terhadap pembelajaran dengan menggunakan model siklus belajar 5E pada materi hukum dasar kimia. Hasil respon mahasiswa terhadap pembelajaran dapat dilihat pada Tabel 1. 
Tabel 1 Respon mahasiswa

\begin{tabular}{|c|c|c|c|}
\hline No. & Aspek yang dinilai & Persentase & Kategori \\
\hline 1 & $\begin{array}{l}\text { Dosen benar-benar mengetahui bagaimana } \\
\text { membuat kami menjadi antusias terhadap materi } \\
\text { pelajaran. }\end{array}$ & 62,9 & Setuju \\
\hline 2 & $\begin{array}{l}\text { Dosen membuat suasana menjadi tegang apabila } \\
\text { membangun suatu pengertian/konsep. }\end{array}$ & 65,8 & Tidak setuju \\
\hline 3 & $\begin{array}{l}\text { Rasa ingin tahu saya sering kali tergerak oleh } \\
\text { pertanyaan yang dikemukakan dan masalah } \\
\text { yang diberikan dosen pada materi pembelajaran } \\
\text { ini. }\end{array}$ & 75,8 & Setuju \\
\hline 4 & $\begin{array}{l}\text { Dosen membuat materi pelajaran ini memang } \\
\text { penting. }\end{array}$ & 73,6 & Setuju \\
\hline 5 & $\begin{array}{l}\text { Saya berpendapat bahwa akan memperoleh } \\
\text { banyak manfaat dari pembelajaran ini. }\end{array}$ & 85,8 & $\begin{array}{l}\text { Sangat } \\
\text { setuju }\end{array}$ \\
\hline 6 & $\begin{array}{l}\text { Manfaat pribadi dari pembelajaran ini jelas bagi } \\
\text { saya. }\end{array}$ & 72,5 & Setuju \\
\hline 7 & Materi pelajaran ini terlalu sulit bagi saya. & 70 & Tidak setuju \\
\hline 8 & $\begin{array}{lrrrr}\text { Di dalam pelajaran ini } & \text { muncul } & \text { rasa } \\
\begin{array}{l}\text { keingintahuan } \\
\text { diajarkan. }\end{array} & \text { saya } & \text { terhadap } & \text { materi } & \text { yang } \\
\end{array}$ & 80 & $\begin{array}{l}\text { Sangat } \\
\text { setuju }\end{array}$ \\
\hline 9 & $\begin{array}{l}\text { Untuk mencapai tujuan, penting bagi saya untuk } \\
\text { berhasil di dalam pembelajaran ini. }\end{array}$ & 95 & $\begin{array}{l}\text { Sangat } \\
\text { setuju }\end{array}$ \\
\hline 10 & $\begin{array}{l}\text { Saya yakin bahwa saya akan berhasil dalam } \\
\text { pembelajaran ini. }\end{array}$ & 82,5 & $\begin{array}{l}\text { Sangat } \\
\text { setuju }\end{array}$ \\
\hline 11 & $\begin{array}{l}\text { Saya berpendapat bahwa tingkat tantangan } \\
\text { dalam tugas yang diberikan di dalam } \\
\text { pembelajaran ini tepat, tidak terlalu gampang } \\
\text { dan tidak terlalu sulit. }\end{array}$ & 78,3 & Setuju \\
\hline 12 & $\begin{array}{l}\text { Jumlah tugas yang harus saya kerjakan } \\
\text { memadai untuk pembelajaran semacam ini. }\end{array}$ & 74,2 & Setuju \\
\hline 13 & $\begin{array}{l}\text { Pembelajaran menggunakan model siklus } \\
\text { belajar membuat saya aktif di dalam kelas. }\end{array}$ & 70,4 & Setuju \\
\hline 14 & $\begin{array}{l}\text { Pembelajaran dengan menggunakan model } \\
\text { siklus belajar memudahkan saya dalam } \\
\text { memahami materi yang diajarkan. }\end{array}$ & 66,7 & Setuju \\
\hline 15 & $\begin{array}{l}\text { Pembelajaran menggunakan model siklus } \\
\text { belajar hanya membuat saya merasa bosan. }\end{array}$ & 74,2 & Tidak setuju \\
\hline 16 & Saya merasa senang karena suasana belajar & 73,9 & Setuju \\
\hline
\end{tabular}




\begin{tabular}{|c|l|c|c|}
\hline No. & \multicolumn{1}{|c|}{ Aspek yang dinilai } & Persentase & Kategori \\
\hline & dibentuk dalam kelompok belajar. & 78,3 & Tidak setuju \\
\hline 17 & $\begin{array}{l}\text { Kerja kelompok tidak membantu saya dalam } \\
\text { memahami materi yang diajarkan. }\end{array}$ & $\begin{array}{l}\text { Sangat } \\
\text { setuju }\end{array}$ \\
\hline 18 & $\begin{array}{l}\text { Kegiatan praktikum membuat saya aktif dalam } \\
\text { pembelajaran. }\end{array}$ & 85,2 & $\begin{array}{c}\text { Sangat } \\
\text { setuju }\end{array}$ \\
\hline 19 & $\begin{array}{l}\text { Kegiatan praktikum membuat saya mengetahui } \\
\text { manfaat materi hukum dasar kimia dalam } \\
\text { kehiduan sehari-hari. }\end{array}$ & 82,6 & Tidak setuju \\
\hline 20 & $\begin{array}{l}\text { Pemberian LKM tidak membantu saya dalam } \\
\text { memahami materi yang diajarkan. }\end{array}$ & 79,2 & Setuju \\
\hline 21 & LKM yang diberikan jelas dan mudah dipahami. & 72,5 & \\
\hline
\end{tabular}

\section{Pembahasan}

Respon mahasiswa diperoleh dari angket respon yang diberikan setelah diberikan perlakuan menggunakan model siklus belajar 5E pada materi hukum dasar kimia. Pertanyaan di dalam angket respon siswa secara umum dibagi ke dalam 9 bagian yang meliputi: respon mahasiswa terhadap dosen dalam menyampaikan pembelajaran, respon mahasiswa terhadap manfaat dari pembelajaran, respon mahasiswa terhadap materi yang diajarkan, respon mahasiswa terhadap tingkat keberhasilan yang diperoleh setelah pembelajaran, respon mahasiswa terhadap tugas yang diberikan dalam pembelajaran, respon mahasiswa terhadap model pembelajaran yang digunakan, respon mahasiswa terhadap kerja kelompok di dalam pembelajaran, respon mahasiswa terhadap kegiatan praktikum dalam pembelajaran, dan respon mahasiswa terhadap lembar kerja mahasiswa (LKM) yang diberikan dalam pembelajaran.

Menurut Arends (2008) studi-studi tentang kelas dan pengajaran menunjukkan bahwa motivasi dan pembelajaran peserta didik dipengaruhi oleh proses dan struktur yang diciptakan pendidik di kelas tertentu. Dalam hal ini, pendidik harus mencoba mengupayakan peserta didik mereka tertarik dengan bahan yang sedang mereka sajikan dan kemudian menyajikannya dengan memikat dan memuaskan maupun meningkatkan keingintahuan peserta didik tentang bahan itu sendiri (Slavin, 2011). Rata-rata respon yang diberikan mahasiswa pada semua item yang dinilai memberikan persentase $\geq 70$, hal ini berarti bahwa rata-rata sebagian besar mahasiswa memberikan respon yang baik terhadap penerapan perangkat pembelajaran yang dikembangkan menggunakan model siklus belajar 5E pada materi hukum dasar kimia. 
Rata-rata respon mahasiswa yang baik dan sangat baik terhadap pembelajaran mengunakan model siklus belajar pada setiap kelasnya disebabkan karena pada model siklus belajar dapat membangkitkan ketertarikan mahasiswa terhadap materi yang akan dipelajari melalui fase engagement, di mana dosen diharapkan membuat suasana belajar menjadi tidak tegang sehingga mahasiswa menjadi antusias dan rasa ingin tahunya meningkat. Selain itu, dosen juga diharapkan dapat meyakinkan mahasiswa bahwa materi yang pelajari penting dan bermanfaat bagi mereka.Fase ini membangun pengalaman mahasiswa untuk memperkenalkan dan mendiskusikan konsep dengan bantuan lembar kerja mahasiswa (LKM). Penting meyakinkan peserta didik tentang penting kadar daya tarik bahan yang akan disajikan, untuk memperlihatkan (jika mungkin) betapa pengetahuan yang akan diperoleh akan bermanfaat bagi peserta didik (Bergin, 1999).

Model siklus belajar juga dapat mempertahankan keingintahuan mahasiswa melalui fase exploration dan fase elaboration. Pada fase explorationmahasiswa dibentuk ke dalam kelompok heterogen yang dapat membantu mahasiswa secara aktif membangun konsep-konsepnya sendiri dengan cara berinteraksi dengan lingkungan sosialnya, baik dengan bimbingan dari dosen maupun kerjasama dengan teman sebayanya dalam satu kelompok dalam melaksanakan praktikum sesuai dengan LKM yang diberikan. Fase elaboration memfasilitas transfer konsep untuk situasi yang sama tetapi baru dengan bantuan LKM lanjutan.Fase ini memberikan kesempatan kepada mahasiswa untuk terlibat dalam situasi dan masalah baru yang memerlukan transfer penjelasan yang indentik. Pembelajaran menjadi lebih bermakna karena mahasiswa diharapkan mampu mengaitkan situasi dan masalah baru dengan struktur kognitif yang telah ada.Menurut Guthrie dan Cox (2001) dalam Slavin (2011) menemukan bahwa pemberian pengalaman langsung ke kegiatan ilmu pengetahuan alam kepada peserta didik sangat meningkatkan pembelajaran mereka dari buku tentang topik terkait dan memberikan lebih banyak motivasi.

Penggunaan penyajian yang menarik pada model siklus belajar dapat dilakukan pada fase explanation untuk memberikan membimbing mahasiswa ke arah pemahaman konsep yang lebih mendalam. Menurut Slavin (2011) Motivasi intrinsik untuk mempelajari sesuatu akan meningkat melalui penggunaan bahan yang menarik, dan juga berbagai jenis cara penyajian.Fase explanation mendorong mahasiswa untuk menjelaskan pemahaman konsep yang telah diperoleh pada fase engagement dan fase explaration dengan 
kalimat mereka, meminta bukti dan klarifikasi dari penjelasan mereka dan mengarahkan pada kegiatan diskusi. Pada fase ini mahasiswa dapat menemukan istilah-istilah dari konsep yang telah dipelajari.

Fase evaluation digunakan dosen untuk menilai pemahaman konsep mahasiswa. Dalam hal ini, mahasiswa diharapkan dapat menentukan tingkat keberhasilan dari pembelajaran yang mereka laksanakan. Menurut Ryan dan Deci (2000) salah satu prinsip mendasar motivasi ialah bahwa orang bekerja lebih keras demi sasaran yang mereka tentukan sendiri daripada sasaran yang ditentukan orang lain bagi mereka. Ditinjau dari dimensi mahasiswa, penerapan model siklus belajar memberi keuntungan sebagai berikut: 1) Meningkatkan motivasi belajar karena peserta didik dilibatkan secara aktif dalam proses pembelajaran, 2) Membantu mengembangkan sikap ilmiah peserta didik dan, 3) pembelajaran menjadi lebih bermakna(Fajaroh \& Dasna, 2007).

\section{Simpulan}

Berdasarkan hasil penelitian dan pembahasan di dalam penelitian, dapat disimpulkan bahwa responmahasiswa yang baik pada pembelajaran menggunakan model siklus belajar 5Epada materi hukum dasar kimia.

\section{Daftar Pustaka}

Adaminata, M. A., \& Marsih, I. N. (2011, September 23). Analisis Kesalahan Konsep Siswa SMA pada Pokok Bahasan Kesetimbangan Kimia. Retrieved Januari 27, 2013, from google.com: http://portal.fi.itb. ac.id/cps/

Arends, R. L. (2008). Learning To Teach Edisi Ketujuh. Yokyakarta: Pustaka Pelajar.

Bergin, D. A. (1999). Influences on Classroom Interest. Educational Psychologist, 87-98.

Cooperstein, S. E., \& Kocevar Weidinger, E. (2004). Beyond Active Learning: a Constructivist Approach to Learning. Emerald Group Publishing Limited, 141-148.

Fajaroh, F., \& Dasna, I. W. (2007, September 20). PEMBELAJARAN DENGAN MODEL SIKLUS BELAJAR (LEARNING CYCLE). Retrieved Oktober 2013, 3, from http://lubisgrafura.wordpress.com: http://lubisgrafura.wordpress.com/2007/09/20/pembelajaran-denganmodel-siklus-belajar-learning-cycle/ 
Gilbert, J. K., \& Treagust, D. (2009). Multiple Refresentation in Chemical Education. Australia: Springer.

Lorsbach, A. (2002). The Learning Cycle as A Tool for Planning Science Instruction. Dipetik Desember 10, 2002, dari http://www.coe.ilstu.edu /scienceed/lorsbach/257lrcy.html.

Prawiradilaga, D. S. (2009). Prinsip Disain Pembelajaran. Jakarta : Kencana.

Ryan, R. M., \& Deci, E. L. (2010). Intrinsic and Extrinsic Motivations: Classic Definitions and New Directions. Educational Psychology, 54-67.

Sirhan, G. (2007). Learning Difficulties in Chemistry: An Overview . Journal of TURKISH SCIENCE EDUCATION, 2-20.

Slavin, R. E. (2011). Psikologi Pendidikan Teori dan Praktik Edisi Kesembilan. Jakarta: PT Indeks.

$\mathrm{Wu}$, C., \& Foos, J. (2010). Making Chemistry Fun to Learn . Literacy Information and Computer Education Journal (LICEJ), 3-7. 